\title{
A Review of Fear of COVID-19 in Society and Discrimination Against Corona Warriors
}

\author{
Shreya Anish Sahu \\ Medical Intern, Jawaharlal Nehru Medical College, Datta Meghe Institute \\ of Medical Sciences, Sawangi, Wardha. Maharashtra, India. \\ Corresponding author email: shreyasahu311997@gmail.com
}

\section{ABSTRACT}

COVID-19, the global pandemic of the decade was declared as an overall health emergency of national and international concern on 30th of January 2020 by World Health Organization.It created a worldwide panic during the recent times. Millions of new cases were being reported daily and considerable mortality was reported.The psychological trauma of loss of near and dear ones and fear and anxiety of isolation affected the attitude of general population towards healthcare workers and professionals.This COVID-19 pandemic is provoking social stigma big time and peculiar behaviour against person of a particular kind of background and also as somebody thought to have being with contact of the virus.In some instance when in the pandemic like condition the incidence of psychosocially morbid are always seems much more than in comparison to normal. The present condition which has been because of former virus, pandemic is causing some increasing worry, emotional stress and fright within population and various groups across the world. This study has attempted to compile the episodes of discrimination against COVID warriors and different aspects of managing psychosocial influences.

\section{KEY WORDS: HEALTHCARE WORKERS, COVID WARRIORS, FRONTLINE WORKERS, DISCRIMINATION, PSYCHOLOGICAL} TRAUMA.

\section{INTRODUCTION}

The global pandemic of the decade whose outbreak I.e. the novel corona virus (COVID-19) have had been long declared as an overall health emergency of national and international concern on 30th of January 2020 by World Health Organization. It's origin which is believed to be of zoonotic origin and has shown a closer genetic similarity to that of a bat's corona viruses vaguely suggesting it's emergence from that of bat-borne virus. Retrospective study and investigations by Chinese and other international authorities have had identified and concluded upon the facts that the initial human

Biosc Biotech Res Comm P-ISSN: 0974-6455 E-ISSN: 2321-4007

\section{crossef}

Identifiers and Pagination

Year: 2021 Vol: 14 No (6) Special Issue

Pages: 202-208

Commons License Attribn 4.0 Intl (CC-BY).

DOI: $h t t p: / / d x$.doi.org/10.21786/bbrc/14.6.43
This is an open access article under Creative cases which showed onset of signs and health related complaints to the former as in early December time in 2019. Those reports suggest that the earliest known and registered cases have links to some wholesale food market chain in city of Wuhan, Hubei China. With the world being a global village and millennial as us, we all live in global economy which includes frequent travels and vacation all around the world, and so did the then dormant viruses too rode along. On 9 0ctober 2020, there have been 37 .

1 million plus cases that have been reported across as many as 188 countries and territories which have had been affected by theCOVID-19 situation resulting in more than 7.55 lakh death around the world. On thebrighter note as of 10 October of 202012.9 million of affected people have recoveredand survived this deadly viral threat. (Du J, et.al. 2020)"The coronavirus pandemic which was caused by a cov19 virus with it's first case found in Europe in Wuhan's Hubei in China on December

\section{Article Information \\ Received: $29^{\text {th }}$ March 2021}

ccepted after revision: $31^{\text {th }}$ May 2021 
of two thousand nineteen. In Jan $23^{\text {rd }}$ of 2020 , the former city with population of roughly 11 million residents entered in a whole city-wide plan of quarantine, and by 29th of the month, each and a every provinces in the country were too entitled to acknowledge the gravity of the situation and had to put up with the plan of quarantine for their own good. Mental trauma and some form of Psychosocial form of distress within extended populations have been reported in country whilts the COVID-19 quarantine."

Overview: Psychosocial and other communal stigma associated with the to the general wellbeing and the bitter association formed by half knowledge wrong assumptions among masses who cause discrimination between a person or by a group of people who share specific disease certain symptoms and certain signs. Such outbreak like the one going on now where many people are stereotyped and socially marginalised and are facing discrimination, while a few who are not treated right, and experience loss of status not economic but of social front if they are in any one way or other linked to person infected by this disease. This peculiar type of outlook may not at all do any good butcan cause the worse and may further affect those withthe disease, as well as those who are there family, caregivers, neighbourhood and eventually society. Some patients who may not be having the same but at all share some or any other kind of similarity which are characteristic to covid 19.

Thesegroup of patients may also suffer from an extended form of stigma. This COVID-19 pandemic is provoking social stigma big time and peculiar behaviour against person of a particular kind of backgroundand also as somebody thought to have being with contact of the virus. (Krishnamoorthy Y, et. Al. 2020) "In some instance when in the pandemic like condition the incidence of psychosocially morbids are always seems much more than in comparison to normal. The present condition which has been because of former virus pandemic is causingsome increasing worry, emotional stress and fright within population and various groups across the world" Across the world and in India as millions of people are staying at home to reduce the transmission and forbreaking the chain of transmission of this severe acuterespiratory syndrome-corona virus, the people working in the health care department and frontline COVID-19warriors are prepared to do the exact opposite.

All of them will go to their clinics, dispensaries and the public workplaces where they have been posted, putting themselves at high riskfrom COVID-19 some reports of the recent times based on various surveillancesconducted of the medical staff depicts both physical as well as mental exhaustion, theconstant lament and torment of the difficult decisions, and even worse is the pain oflosing the patients and next of kins and sometimes co-worker, this all and still the riskprevails. The health care workers who are involved in treating coronavirus patients inour country are getting threats and landlords are pressuring them to vacate homes.

Forinstance an example from a housing society situated in Ghaziabad which has now denied theentry to doctors, nurses and residents who are health practitioners, and thus asking them to stay incapital Delhi instead, causing major mental distress for the society's resident doctors, nursesand other people who work in healthcare department. In the news as it is stated The "Neelpadam Kunj Society" Apartment Owners Association in Ghaziabad has requested its residents who are doctors, nurses, and other people who work in healthcare department who are working in nation'scapital Delhi to make some sort of temporary arrangements for their stay in the nation's capital Delhi.Such arrangements were needed near the hospital setup because of fears that doctors, nurses, and other people who work in healthcare department may spread coronavirus to the common people living in that area. While in metros such situations prevail so it's not that hard to think how thegrassroots level of country the villages and smaller towns and cities are dealing with thesame.

Even after the daily telephonic campaign and various media campaign by Govt. of India which states and urges people to stop discriminatingbetween the recovering patients and the doctors who treat them, still the discriminationprevail. We can too follow the examples from china where (Zhu J, et. Al. 2020)"A cross-sectional study design had been conducted atGansu (China), where with help of a questionnaire that was contained of many scales and parameters like the self-rating scales like :1. anxiety scale aka $\{S A S\}, 2$. A depression scale aka $\{$ SDS $\}$, lastly simplified coping style questionnaire $\{\mathrm{SCSQ}\}$. As many as around 80 doctors and around 85 nurses took part in thissimple survey. It's further analysed and looked at correlations amongthe above scores. A model showing linear regression has been used to demarcate and to know various factors that influence it". Similar models can be carried out in India to look at the impact of the current situations on the health care providers and hospital staff of our country.

Stigma related with health care workers: The mental fight for Lisa Jose* started at night of 4th of April, when she received a call from the multi-specialisation dispensary her workplace as a nurse in New Delhi came. She was informedthat she had to go into quarantineimmediately as she had been tested positive in the test for Covid19. Initially the authorities at the hospital had made it clear to all the staff nurse and other health care workers that they will not admitting patients suffering from Coronavirus. Then Jose, who was expecting a month later 
and heavily pregnant at the time, anticipated that she was not at risk of contracting the virus. But as early as one working doctor was confirmed to be having covid-19 contamination, all of the ones who had reported him on their day of duty were asked to undergo a test.

Soon after she received a call from the hospital, she packed up her briefcase and was sitting awaiting the ambulance and at the same time tryingher best by keeping away her son who was then 1year-old . But as they lived in an only two rooms house the situation was not alleasy. She later told the interviewing magazine over the cellphone. The much awaited ambulance didn't show upthat whole night. As she had begun her wait for the ambulance, sitting all alone, at around 9:30 pm.Talking of her mental trauma at that time, she wasn't able to sleep peacefully oreven lie down either. After making several phone calls to the hospital, the ambulance finally arrivedat $4 \mathrm{pm}$ the following evening. While they are the one who work as frontliners to fight the pandemic, health staff like Jose have realised that their job in no ways is an easy one.

Similarly, Dr. Singh, a resident doctor working as a frontliner atall India institute of medical sciences at Bhopal ,Indore, writesto the daily mailthat a policeman attacked him while he was on his way back to his place from an urgent duty during night. Dr.Singh reported that the policepersonnel said to him that it was doctors like him were actually responsible for such rampant virus spread.A similar case happened in New Delhi, when two doctors were ferociously attacked by a middle aged man, the doctors were going out to buy some fruits when the attack happened, the man afteraccusing doctors for the spread of the virus tried to hit them. He was later taken into custody. If these were no better where attacks are by strangers, a practicing psychiatristat GujaratSurat, finally concluded that the neighbourhood she had been living with were no better. After returning home from hospital she was staying in since the past few years her neighbour said to her that he was somehow contemplating that she had been infected by the same.

Very next day that same person who talked to her the day before begancalling her names, shouting on her and evenharming her by finding ways to somehow to hit her. After seeing this act of him of attacking by the neighbour, the psychiatrist's 3 yr old started wailing aloud and throwing tantrum. These sorrowful situations are a shame and disgrace to society. As of in china province where the hospital management managed the situation as follows wherein the " theFrontline doctors, especially those in Wuhan, who had come in close contact with the virus infected patients complained of heavy workload, loneliness and marginalisation. It is because of which and they are quite likely to feel physical exhaustion and emotion disturbance with sleep issues. A study which involved 1,563 healthcare workers found that a few more than half the participantshad report depressive symptoms, some $44.7 \%$ anxiety, and 36.1\% sleep disturbance." (Li W, et. Al. 2020).

Management of mental Stress which came with the corona virus outbreak on healthcare personnel's: The complete wellbeing emotional and mental health of health care personnel are one of the most important components for maintaining the good rapport of health care service providers during the COVID-19 virus (corona virus) outbreak. Therefore, it is need of the hour to manage the stress associated with this type of work and have a solid form of support for health care personnel's. Assessing and monitoring of psychological health with the total well-being of frontline health care providers is of the utmost importance, along with the necessary efforts to ensure positive environment with work colleagues. Institutional support with some selfcare strategies are need of the hour.

Dealing with Stress through Preparedness: Health care personnelare advised to show active participation in frequent institutional andNon institutional training session. Organizational efforts should continue during the COVID-19outbreak as they provide an effective way of overall stress reduction. Health care personnelneed proper training in detail about the modes of transmission of the SARS COV-2 virus, how to screenany patient or their family members, instruction regardingcorrect use of personal protective equipment (PPE), when and by which modes to practice quarantine when necessary. In order to increase their efficacy in the work, workers ought to actively take part in some of proper training and planning exercises that include.

- Taking responsible roles

- Knowledge of all the types and levels of quarantine

- statistics about movement and restrictions for patient suffering from the disease

- proper management of the limited resources available

- proper management of mass fatalities

- conduction of frequent mental health screenings

- proper management ofthe high stress

Staff and the health care faculties should also meet with theirrespective leaders to discuss about the psychosocial support and stress management for all of the working staff.Discussions must include the proper ways of stress control and management, an appropriate work schedules with short rotational shifts and time to rest, and mental as well as any other type of support for healthcare workers' family members. (Wang C, et. Al. 2020). 
Ways to Manage Psychosocial Stigmas: Social studies and research states that the social stigma and fright revolving around thesecontagious diseases are dampening the required results. What at all works the best is renewing of trust within the trustworthy health care services or advice, showing gratitude and empathy to the ones who were once infected, properly knowing aboutthe nature and type of the disease, and last but not the leastsome practical and effective ways so as the people can look up to to keep themselves and also their relatives safeguarded. How it's communication takes place with regards to coronavirus is very crucial for helping people in taking actions effectively that will help to combat and curb the disease and to further help in avoiding the fuelling of social stigmaand social fear. The current need is an environment in which there will be correct information about the virus, it's course and tremendous outcomes if not treated in it's earlier stages can be talked outand talked freelyso as to educate the less knowledgeable ones which will definitely be of much good. Some cues are as follows.

1. Verbal cues to deal with situation: what to avoid while talking about the COVID-19 pandemic

2. Doing our part at grass root level

3. Communication via simple tips and messages

Verbal cues to deal with situation: When conversing about the novel coronavirus, certain statements and phrases like suspected of infection, isolation or any other such words which is related to corona case andmay have a negative impact on people or which might fuel some type of stigmatizing attitude from the most of the people. This may lead toincrease in the present existing negative stereotypes and many false assumptionsregarding the virus andmay even strengthen thepresent false associations between the disease and about the some of the factors, creating a widespread fear and can even prove dehumanizing to those who have the disease.

This can lead to have a huge impact that may further discourage most of thepeople from getting tested for the test for covid or getting at least screened and also from getting quarantined when it is quiet necessary. It is therefore recommended for better that the useof' masses mouther tongue(language)whichempowers with at the same time respects society in most ofits interacting ways which includes social media. Verbal cues used in any kind of media formatare specially of prime importance, as this is what will shape the right opinion and modes of transmission about the disease (COVID-19). Any type of wrong statements have time and again to be potent enough to influence how health care personnel are thought to been contracted new novel coronavirus, their colleagues and their next of kins.

\section{DISCUSSION}

What should be done and what should be avoided. There are listed below and they are as follows.

\section{What Can be Done:}

1. "Like in the case of Peking Union Medical College. Where doctors, nursing staff of covid clinic who were selected by the Emergency Department looking at their years of experience and ability to adapt under such pressure based on their past works. Psychological support was their priority too. A hotline service was put up from 9 morning to 9 evening each day, to have one on one communication with medical workers, to provide much needed support and help them find some emotional support."( Cao J, et. Al. 2020) Speak up and educate each and every one about the coronavirus disease.

2. Speak up more of the health care workers who are receiving proper treatment for the COVID-19disease, those doctors having the disease, and those health care professionals are on stage of recovering from the disease or health care workers who havecompletely recovered from the COVID 19 and regained a COVID19 negative status.

3. As in few states of china where (Kang L et. Al. 2020) "initiatives like psychological help hotlineprovide helpand guide todeal with any psychological aliments,many medical workers are getting help via this interventions, with abetter outcome, they have decided to expand such help to the masses too.Talk about the useful services the health care providers provided that hadbenefited many patients when they were under their care and supervision and how theyrecovered.

4. Talk about health care worker's contribution to the society during other diseasesoutbreak in the community even before the COVID-19 pandemic.

\section{What Can Be Avoided:}

1. Talking about how only it is the health care workers who are solely responsible forspreading the chain of causation and are transmitting COVID-19 or are they are theones spreading the virus as it implies on assigning blame as they get infected mostlywhen they are treating patients of COVID19. Using criminalizing and dehumanising termson them creates an impression as if those infected by the disease had by some means done thing utterly wrong and are vile and are less human than any rest of us all, notshowing any amount of empathy, fuelling stigma and probably intensifying the fuel of amuch wider reluctance to their desire to serve society which they do selflessly as theyhave done so far and might not be a good example for other health providers aroundthem and will be a big toll on the pillar of society. 
2. Attacking verbally and defaming the physicians (who had detected that a patient mightbe infected by COVID-19 based on sign and symptoms) as false predictors and accusingthem of doing so making assumptions they are doing it only for monitor gains.

3. Calling out professionals suffering with the disease as corona or COVID-19case.

4. Talking negative and taunting health care workers as suspect cases or as COVID-19Suspect.

5. False journalism and fake news about private practitioners that their hospitals areinfected even if it is disinfected and fumigated at regular intervals or whenever requiredduring emergence (if at all a suspected patient tests RT PCR COVID-19 positive).

The Governments of India, our media, various" influencers and influential people8doShare a tremendous role play in prevention the social stigma around the presentsituation and gravity of the situation." We all need to play our part and be thoughtfulwhen we are conversing via social media platform and on many other media, platforms, portraying a helpful outlook when talking about such sensitive andsocially stigmatized topic like the one around the new coronavirus disease (COVID-19).As with case of wuhan china based on study "A total of 5317 women health workers who were surveyed, and 4369 legit responses were collected, with an highresponse rate. 621women health workers were with depressed, and showed acute stress symptoms"( Li G, et. Al. 2020) post the start of coronavirus based on cross- sectionaldesign of study.

We can look up to some points on possible ways to destigmatize and improve people's attitudetowards the disease:

1. As India is after all a country of numerous religions and faith so engaging some influential people like various religious leaders on changing outlook of people about the people suffering from the disease and guide them the ones who are stigmatized and put forth ideas about supporting them.

2. Celebrities too can help on putting forth the messages which will help to reduce the social stigma. The information that they are putting forward to the mass public should be double checked and the celebrated people and influencers approached to communicate the same information should be asked to personally, professionally engage in such noble endeavours, and at the same time the geographic and cultural correctness on being the key to people as in today's world of internet converting world to a global village and people being aware of the issues and their rights.

3. Quoting examples by various surveys and individuals projects about theimprovements in the mortality rates after early and proper medical sciencesintervention.

- The stories and voices, and the pictures of local doctors and other frontline worker'swho have braved all odds and came out of the new novel coronavirus (COV-19) andhave recovered and most importantly the ones who have been there for themthroughout and supported them and their loved ones who throughout their recovery hadto stick to facts that recovery rates are high too. Giving them a status of trueCOVID WARRIORS AND HEROS IN TIME OF NEED, such small scale and large scalecampaign honouring and glorifying the caretakers and healthcare workers should becarried to let the message to the masses which will help a lot in destigmatising thesituation.

- The volunteers who have also played an important and greater role in reducing stigmain communities should be felicitated on virtual platforms and such programmes can beshown on local news channels and social media platform to help boost their morals andencourage them to keep up the good work.

- Making sure that we portray different ethnic groups coming forward and uniting to helpout our health care workers should be promoted it should be made clear that as thehealth care workers never make a discrimination while treating patients irrespective oftheir ethnicity so shouldn't be the people. All media should dutifully showcase how if thecommunity is being impacted all the other communities are volunteering to help. Ensuring various religious symbols, flags of the cults are neutralised and doesn't make any such strong andbiased suggestions about a particular group.

- Medial journalism: The Journalists who are reporting on the same issues as that ofthe pandemic and the ones which solely focused on individual outlook and patients'responsibility for spreading on of the chain of causation and "spreading COVID-19" canhelp by putting forward some positive news and reports showing a brighter side duringthese dark times which will help to decrease stigma.In the current scenario as the times are changing so is the role of medical and news journalist in the digital distribution of research results. When the quality needs have to be met from these contents." (Daube D, et. Al. 2020) this can redefine the role of news journalists.

4. Various media outlets have which have so far mostly focused on finding and showing the source of COVID-19, and are putting in efforts to put forth a" 0 patient "status of some places\ which are on a brighter side not affected by the situation or had once been affected butnow the disease has been cribbed in each country. Such example if put forward canhelp a lot in people to reach common goals (Toshida, T., and Chaple J 2020, Ather B,et. Al. 
2020, Shah, P., and Naqvi W, 2020, Gaidhane S,et. Al. 2020 and Jachak, S.,et. Al 2020).

5. Instead of pointing out on efforts of health care workers and their tireless efforts to putforth a vaccine for the same and treatment of COVID-19 which can in turn increase fearand give a negative impact on society that is that we are not powerfully enough to haltthe course of the disease we can instead, promote information around basic infectionprevention practices, handwashing techniques being the key. A number of studies related to this article were reviewed (Joseph, M.B., S. Pohekar, 2020, Joshi, K., et. al. 2020 and Lakhkar, B.B., et. al. 2020). Studies on fear, depression (Jonas, et. al. 2014) discrimination (Joge, et. al. 2013) were reported. (Vagga et.al.2021) reported about Yoga and Meditation during corona lockdown. Studies by (Dhadse et. al. 2020, Dhok et.al. 2020, Gawai et.al. 2020 and Phansopkar et. al. 2020)addressed various aspects of fear and stress during corona pandemic.

\section{CONCLUSION}

Stigma cannot be crumbled as long as insufficient and improper information regarding how coronavirus disease is spread and hoax remedies of treatments prevail it can be of much harm to community. As is said half knowledge can be a very dangerous thing which actually holds to be very true to this situation whilst we are still figuring out on and how to prevent infection. Instead ofputting in all the energies on prioritise the collection, compiling and showcasing all ofperfect daily score of region, nation and area specific data about affected and contaminated places,individuals, group and theirpossibility to catch COVID-19, management options andinstitution of accessing health care knowledge we should try to find ways to break thechain if causation and transmission. Use of simple language and as of 2020 avoiduse of certain clinical terms as it may scare off layman and add to already going onstigma.

\section{REFERENCES}

Ather, B., Mirza, T.M. and Edemekong, P.F., 2020. Airborne precautions. StatPearls [Internet].

Cao, J., Wei, J., Zhu, H., Duan, Y., Geng, W., Hong, X., Jiang, J., Zhao, X. and Zhu, B., 2020. A study of basic needs and psychological wellbeing of medical workers in the fever clinic of a tertiary general hospital in Beijing during the COVID-19 outbreak. Psychotherapy and psychosomatics, p.1.

Daube, D. and Ruhrmann, G., 2020. Introduction to the quality of medical journalism and initial assessments of COVID-19 media coverage. Bundesgesundheitsblatt, Gesundheitsforschung, Gesundheitsschutz.

Dhadse, P.V., Sethiya, K.R., Subhadarsanee, C. and Durge, K., 2020. The novel corona virus (nCoV2) seems to defy all laws of virology.
Dhok, A., Butola, L.K., Anjankar, A., Shinde, A.D.R., Kute, P.K. and Jha, R.K., 2020. Role of Vitamins and Minerals in Improving Immunity during Covid-19 Pandemic--A Review. Journal of Evolution of Medical and Dental Sciences, 9(32), pp.2296-2301.

Du, J., Dong, L., Wang, T., Yuan, C., Fu, R., Zhang, L., Liu, B., Zhang, M., Yin, Y., Qin, J. and Bouey, J., 2020. Psychological symptoms among frontline healthcare workers during COVID-19 outbreak in Wuhan. General hospital psychiatry.

Gaidhane, S., Khatib, N., Zahiruddin, Q.S., Gaidhane, A., Telrandhe, S. and Godhiwal, P., 2020. Depression, anxiety and stress among the general population in the time of COVID-19 lockdown: A cross-sectional study protocol. International Journal of Research in Pharmaceutical Sciences, 11(Special Issue 1).

Gawai, J.P., Singh, S., Taksande, V.D., Sebastian, T., Kasturkar, P. and Ankar, R.S., 2020. Critical Review on Impact of COVID 19 and Mental Health.

Jachak, S., Phansopkar, P. and Naqvi, M.W., 2020. Impact of covid-19 in India, a disastrous pandemic outbreak. International Journal of Research in Pharmaceutical Sciences, 11(Special Issue 1).

Jonas, J.B., Nangia, V., Rietschel, M., Paul, T., Behere, P. and Panda-Jonas, S., 2014. Prevalence of depression, suicidal ideation, alcohol intake and nicotine consumption in rural Central India. The Central India Eye and Medical Study. PLoS One, 9(11), p.e113550.

Joseph, M.B., Pohekar, S., Raut, A. and Patil, M., 2020. The palliative care and covid-19 pandemic. International Journal of Research in Pharmaceutical Sciences, 11(Special Issue 1).

Joshi, K., Acharya, N., Acharya, S. and Joshi, S., 2020. A grave situation with COVID in the gravid: A narrative review. International Journal of Research in Pharmaceutical Sciences, pp.496-499.

Joge, U.S., Deo, D.S., Choudhari, S.G., Malkar, V.R. and Ughade, H.M., 2013. " Human immunodeficiency virus serostatus disclosure-Rate, reactions, and discrimination": A cross-sectional study at a rural tertiary care hospital. Indian Journal of Dermatology, Venereology, and Leprology, 79(1), p.135.

Kang L, Li Y, Hu S, Chen M, Yang C, Yang BX, Wang Y, Hu J, Lai J, Ma X, Chen J. The mental health of medical workers in Wuhan, China dealing with the 2019 novel coronavirus. The Lancet Psychiatry. 2020 Mar 1;7(3):e14.

Krishnamoorthy, Y., Nagarajan, R., Saya, G.K. and Menon, V., 2020. Prevalence of psychological morbidities among general population, healthcare workers and COVID-19 patients amidst the COVID-19 pandemic: A systematic review and meta-analysis. Psychiatry research, 293, p.113382.

Lakhkar, B.B., Guru, B., Damke, S. and Damke, S., Most Susceptible Duo in COVID-19 Crisis: A Literature Review. Perinatology, 21, pp.112-23.

Latchoumi, T.P., Ezhilarasi, T.P. and Balamurugan, K., 
2019. Bio-inspired weighed quantum particle swarm optimization and smooth support vector machine ensembles for identification of abnormalities in medical data. SN Applied Sciences, 1(10), pp.1-10.

Li, G., Miao, J., Wang, H., Xu, S., Sun, W., Fan, Y., Zhang, C., Zhu, S., Zhu, Z. and Wang, W., 2020. Psychological impact on women health workers involved in COVID-19 outbreak in Wuhan: a cross-sectional study. Journal of Neurology, Neurosurgery \& Psychiatry, 91(8), pp.895897.

Li, W., Yang, Y., Liu, Z.H., Zhao, Y.J., Zhang, Q., Zhang, L., Cheung, T. and Xiang, Y.T., 2020. Progression of mental health services during the COVID-19 outbreak in China. International journal of biological sciences, 16(10), p.1732.

Phansopkar, P.A., Naqvi, W.M. and Sahu, A.I., 2020. COVID-19 Pandemic-A Curse to the Physical Well-Being of Every Individual in Lock-Down. Journal of Evolution of Medical and Dental Sciences, 9(35), pp.2561-2567. Roy, D., Tripathy, S., Kar, S.K., Sharma, N., Verma, S.K. and Kaushal, V., 2020. Study of knowledge, attitude, anxiety $\&$ perceived mental healthcare need in Indian population during COVID-19 pandemic. Asian journal of psychiatry, 51, p.102083.
Shah, P. and Naqvi, W., 2020. Fighting and chasing the rogue virus-covid19. International Journal of Research in Pharmaceutical Sciences, 11(Special Issue 1).

Vagga, A.A. and Dhok, A.J., 2020. Blessings in Disguise: Yoga and Meditation during Corona Lockdown. Journal of Evolution of Medical and Dental Sciences, 9(35), pp.2540-2545.

Wang, C., Pan, R., Wan, X., Tan, Y., Xu, L., Ho, C.S. and Ho, R.C., 2020. Immediate psychological responses and associated factors during the initial stage of the 2019 coronavirus disease (COVID-19) epidemic among the general population in China. International journal of environmental research and public health, 17(5), p.1729.

Yethindra, V., 2020. Role of GS-5734 (Remdesivir) in inhibiting SARS-CoV and MERS-CoV: The expected role of GS-5734 (Remdesivir) in COVID-19 (2019-nCoV)VYTR hypothesis. International Journal of Research in Pharmaceutical Sciences, 11(Special Issue 1).

Zhu, J., Sun, L., Zhang, L., Wang, H., Fan, A., Yang, B., Li, W. and Xiao, S., 2020. Prevalence and influencing factors of anxiety and depression symptoms in the firstline medical staff fighting against COVID-19 in Gansu. Frontiers in psychiatry, 11. 